\title{
PESANTREN SEBAGAI LEMBAGA PENDIDIKAN YANG EFEKTIF
}

\author{
Fauziah \\ Dosen Program Studi Pendidikan Agama Islam \\ Sekolah Tinggi Ilmu Tarbiyah Malang \\ Email: Fauziahaftania@gmail.com
}

\begin{abstract}
Abstrak
Pesantren merupakan sebuah lembaga pendidikan yang menitikberatkan pada pendidikan agama dengan membekali santrinya pengetahuan agama yang cukup melalui kajian kitab kuning sebagai sumbernya. Pendidikan yang dijalankan di dalamnya efektif dalam kaitannya dengan tujuan pendirian pesantren dan lulusannya yang memiliki kedalaman spiritual sehingga dapat memberikan arah yang benar terhadap masyarakat pada masa yang akan datang. Oleh karena itu pendidikan yang efektif telah dijalankan dengan baik oleh lembaga tersebut.
\end{abstract}

\section{A.Pendahuluan}

Lembaga pendidikan yang efektif menuntut adanya perencanaan yang tepat sesuai dengan kebutuhan zaman dimana berbagai sisi kehidupan mampu dijangkau dengan baik. Dalam upaya membentuk peserta didik yang baik sesuai dengan kompetensi, maka beberapa komponen dalam pendidikan harus dimiliki secara sempurna dan terpenuhi dengan baik pula.

Untuk memberikan pelayanan yang baik, maka sebuah lembaga pendidikan harus melaksanakan tugas dan fungsinya khususnya dalam menyelenggarakan pembelajaran dengan baik. Oleh karena itu, lembaga pendidikan ada kalanya bersifat tradisional dan adakalanya bersifat modern yang keduanya masih berjalan sampai saat ini dan akan terus dipertahankan sebagai ciri khas dan sesuai dengan visi dan misi pendirian awal lembaga tersebut. 


\section{Fauziah}

Menurut Azyumardi Azra ada beberapa lembaga pendidikan Islam yang bersifat tradisional diantaranya surau, langgar, madrasah dan pesantren ada juga perguruan tinggi dan madrasah¹. Lembaga-lembaga ini diharapkan dapat menyalurkan pola keberagamaan mereka dalam berkehidupan yang baik.

Adakalanya lembaga pendidikan selalu melakukan pengembangan sistem pembelajarannya yang dikemas dalam pendidikan formal yang berupa madrasah, dan ada juga yang dikemas dalam pendidikan non formal yang berupa pesantren, bahkan ada yang pesantren yang menyelenggarakan pendidikan formal dan non formal sekaligus dalam satu naungan. Apapun bentuk sistem pendidikan yang dibangun, maka tentunya memiliki tujuan dan program tersendiri.

Pesantren diklaim sebagai lembaga pendidikan yang mampu menjalankan perannya dalam mengawal pendidikan agama Islam. Di dalamnya para santri dididik untuk bersiap menerima pelajaran agama yang cukup serta bersiap menjadi agen religius corner pada masa mendatang di tengah-tengah masyarakat yang tentunya akan selalu mengalami kedinamisan.

Perkembangan pesantren telah berhasil membekali lulusannya menjadi ahli dalam beragama yang siap terjun di masyarakat. Hal ini tentunya sejalan dengan program pendidikan yang relevan dimana beban pengetahuan agama dibenamkan pada diri mereka. Hal inilah yang menjadi dasar bahwa pesantren benar-benar

\footnotetext{
${ }^{1}$ Azyumardi Azra dalam pengantar Abudin Nata (editor), 2001, Sejarah Pertumbuhan dan Perkembangan Lembaga-Lembaga Pendidikan Islam Di Indonesia, Jakarta, Grasindo, Hlm. Viii
} 
menjadi sebuah lembaga pendidikan yang efektif yang mencetak generasi Robbani yang memiliki ketajaman religius yang kuat.

\section{B. Posisi Pesantren dalam Lembaga Pendidikan Islam}

Masyarakat Indonesia merupakan masyarakat yang selalu mengedepankan semangat kebersamaan dalam bertindak dan bekerja sama dalam kemajuan. Bersamaan dengan hal tersebut, sejak awal berdirinya bangsa Indonesia melalui tokoh pendidikan dan pahlawan kemerdekaan telah mencetuskan terbentuknya pendidikan non formal secara integratif. Usaha membangun manusia seringkali dikaitkan dengan pendidikan, sehingga dalam banyak aktifitas selalu terdorong semangat saling menasehati dengan hak dan sabar.

Pendidikan secara luas merupakan usaha membangun seseorang untuk lebih dewasa, ataupun juga pendidikan adalah suatu proses transformasi anak didik agar mencapai hal-hal tertentu sebagai akibat proses pendidikan yang diikutinya. Sebaliknya menurut Jean Praget bahwa pendidikan berarti menghasilkan atau mencipta walaupun tidak banyak, dan dapat juga diartikan segala situasi hidup yang mempengaruhi pertumbuhan individu sebagai pengalaman belajar yang berlangsung dalam segala lingkungan dan sepanjang hidup. ${ }^{2}$

Pesantren sebagai agen pengembangan pendidikan agama Islam memiliki andil dalam memanusiakan manusia dengan berbagai kegiatan proses pembelajaran yang

\footnotetext{
${ }^{2}$ Syaiful sagala, 2006, Konsep dan Makna Pembelajaran, Bandung : alfabeta . cet.4, Hlm,.1
} 


\section{Fauziah}

khas dan hanya dimiliki oleh bangsa Indonesia. Pengalaman belajar di pesantren tentunya tidak terbatas usia dan waktu karena pada dasarnya tujuan pendidikan pesantren adalah untuk mendalami ilmu agama Islam, sehingga lembaga ini tidak membatasi jumlah santrinya, batasan materinya, keberagaman usia yang dirasa cukup dan siap untuk belajar dan digembleng dengan mempraktekkan kegiatan spiritual.

Lembaga pendidikan ialah komponen pendidikan yang menjadi tempat atau lingkungan pendidikan, yang menurut Ahmad Tafsir bahwa secara konseptual lembaga pendidikan (sekolah) dibentuk untuk melakukan proses pendidikan dalam mencapai tujuan pendidikan. Tiga tujuan setidaknya ingin dicapai melalui sekolah yakni moralitas (akhlak), civic (cinta tanah air), dan berpengetahuan. ${ }^{3}$

Penetapan tujuan lembaga pendidikan Islam menjadi hal yang mutlak untuk ikut serta dalam mencerdaskan kehidupan bangsa. Melalui komponen pesantren, maka diharapkan tercipta suasana yang kondusif dalam membentuk peserta didik yang memiliki moralitas yang baik yang diimplementasikan dalam kehidupan sehari-hari sehingga wajar jika santri kerap bersikap tawaddu (rendah diri) dalam bersikap, cinta tanah air yang diwujudkan dalam solidaritas yang kuat dalam melaksanakan perintah sang Kyai, serta pengetahuan agama yang cukup sebagai bekal mengisi dan membekali dirinya menjadi orang yang berjiwa luhur.

\footnotetext{
${ }^{3}$ Ahmad Tafsir, 2006, Filsafat Pendidikan Islami: Integrasi Jasmani, Rohani dan Kalbu Memanusiakan Manusia, Bandung: Remaja Rosdakarya
} 
Wacana kelembagaan pendidikan Islam khususnya pada masa-masa awal merupakan persoalan yang sangat menarik untuk dikaji, hal ini setidaknya disebabkan oleh empat faktor. Pertama, lembaga pendidikan merupakan sarana yang strategis bagi proses terjadinya transformasi nilai dan budaya pada suatu komunitas sosial. Kedua, pelacakan eksistensi lembaga pendidikan Islam tidak bisa dilepaskan dari proses masuknya Islam Ketiga, kemunculan lembaga pendidikan Islam dalam sebuah komunitas, tidak mengalami ruang hampa, tetapi senantiasa dinamis, baik dari fungsi maupun sistem pembelajaranya. Keempat, kehadiran lembaga pendidikan Islam telah memberikan spectrum tersendiri dalam membuka wawasan dan dinamika intelektual Islam. ${ }^{4}$

Posisi pesantren dalam pengembangan pendidikan Islam tampak pada perannya dalam menjadi sarana transformasi nilai dan budaya yang diinternalisasikan dalam unsur-unsur pesantren yang bergerak mengiringi tuntutan agama. Di satu sisi, pesantren memiliki andil dalam ikut serta membawa kemerdekaan bangsa Indonesia dalam rangka mengusir penjajah, sehingga ketaatan santri pada Kyai inilah yang membawa motivasi tersendiri dalam menanamkan semangat spiritualitas keagamaan serta semangat membela tanah air sebagaimana juga dituntutkan dalam agama.

Sejak berdirinya pesantren, para orang tua percaya bahwa pesantren akan mampu membenahi moral dan akhlak putranya dengan sekaligus membekalinya

\footnotetext{
${ }^{4}$ Samsul Nizar, 2001, Lembaga Pendidikan Islam di Nusantara, Jakarta, Grasindo , Hlm. 6
} 


\section{Fauziah}

dengan pengetahuan agama yang cukup. Di samping itu, para lulusan pesantren diharapkan dapat menjadi penerus orang tua dalam berinteraksi di masyarakat serta menjadi panutan dalam kehidupan sehari-hari.

Selain itu, orang tua juga dituntut untuk mempersiapkan anaknya sebagai anggota masyarakat yang baik, sebab masyarakat yang baik berasal dari individuindividu yang baik sebagai anggota dari suatu komunitas masyarakat itu sendiri. Mengenai hal ini, Allah Swt menegaskan dalam QS. Ar-Ra'du (13:11,) yaitu:

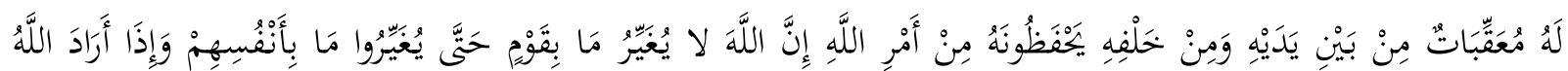

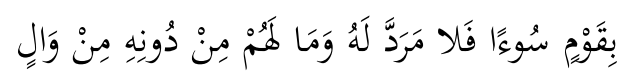

Artinya: "Bagi manusia ada malaikat-malaikat yang selalu mengikutinya bergiliran, di muka dan di belakangnya, mereka menjaganya atas perintah Allah. Sesungguhnya Allah tidak mengubah keadaan sesuatu kaum sehingga mereka mengubah keadaan yang ada pada diri mereka sendiri. Dan apabila Allah menghendaki keburukan terhadap sesuatu kaum, maka tak ada yang dapat menolaknya; dan sekali-kali tak ada pelindung bagi mereka selain Dia."(Ar$\left.R a^{\prime} d u, 13: 11\right)$

Ayat di atas menjelaskan bahwa upaya membangun budaya masyarakat harus dilakukan sejak dini, mengingat karakter manusia harus membiasakan apa yang harus dilakukan, maka pembiasaan baik juga perlu dilaksanakan. Oleh karena itu, pesantren memfasilitasi pembiasaan baik juga disiplin dalam mengikuti pengajian dan mandiri dalam melakukan seluruh kegiatan dan kebutuhan santrinya. Dengan demikian, individu yang baik akan muncul dari adanya pesantren ini juga meminimalisir kebiasaan buruk yang mungkin dimiliki oleh santri. 
Peran pesantren dalam pendidikan Islam tertuang dalam pandangan berikut ini ysng berkaitan dengan usaha menyukseskan misi dalam tiga macam tuntutan hidup seorang muslim yang dapat diimplementasikan dalam lembaga pendidikan Islam adalah sebagai berikut ${ }^{5}$ :

1. Pembebasan manusia dari ancaman api neraka, sesuai dengan perintah Allah :

$$
\text { قُوْا أَنْفُسَكُمْ وَأَهْلْيْكُمْ نَارًا }
$$

Artinya: "Jagalah dirimu beserta keluargamu dari ancaman api neraka".

2. Pembinaan manusia menjadi hamba Allah Swt yang memiliki keselarasan dan keseimbangan hidup bahagia didunia dan diakhirat sebagai realisasi cita-cita orang yang beriman dan bertaqwa.

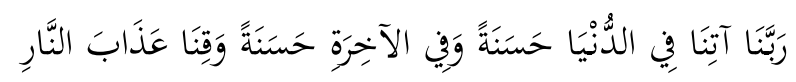

Artinya:"Wahai tuhanku, berilah aku kehidupan didunia yang sejahtera dan berilah kehidupan di akhirat yang bahagia dan jauhkanlah kami dari siksa api neraka".

3. Membentuk diri pribadi manusia yang memancarkan sinar keimanan yang kaya dengan ilmu pengetahuan, yang satu sama lain saling mengembangkan hidupnya untuk menghambakan dirinya kepada Khaliknya. Keimanan dikendalikan oleh akal budinya. Firman Allah :

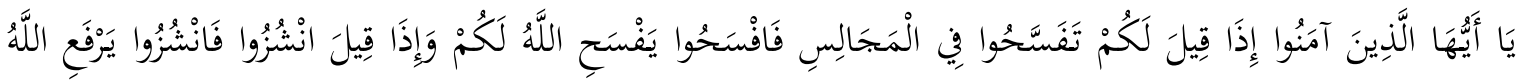

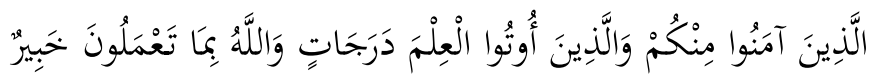

Artinya :" Hai orang-orang yang beriman, apabila dikatakan kepadamu: "Berlapanglapanglah dalam majelis", maka lapangkanlah, niscaya Allah akan memberi kelapangan

\footnotetext{
${ }^{5}$ Manba'ul Uluum, 2012, Filsafat Pendidikan Islam; Lembaga Pendidikan Islam dan Tantangan Modernisasi. Diakses tanggal 3 Maret 2013 pada, http://manbaululuumgs, blogspot.com
} 


\section{Fauziah}

untukmu. Dan apabila dikatakan: "Berdirilah kamu, maka berdirilah, niscaya Allah akan meninggikan orang-orang yang beriman di antaramu dan orang-orang yang diberi ilmu pengetahuan beberapa derajat. Dan Allah Maha Mengetahui apa yang kamu kerjakan." (AlMujadalah, 58: 11)

Tuntutan kehidupan manusia dalam rangka mencari jatidirinya dengan melakukan pendekatan agama menjadi tujuan dalam setiap langkahnya. Sebagaimana dijelaskan dalam ayat di atas, bahwa umat Muslim diperintahkan untuk menjaga diri dan keluarga dari siksa api neraka. Hal ini menandakan bahwa upaya mengawal dari gemerlap duniawi yang jauh dari nuansa keagamaan harus dilakukan dengan amal shalih. Oleh karena itu, pesantren sebagai lembaga pendidikan Islam berperan dalam membentengi diri, keluarga dan orang sekitar dengan kegiatan yang akan mendatangkan dosa.

Persembahan kepada Sang Maha Pencipta (Khalik) selalu dilakukan oleh umat Muslim dengan memperbanyak ibadah, dzikir dan doa yang dilakukan setiap waktu agar seluruh hidupnya diberkahi dan diridhoi oleh Allah Swt. Dalam hal ini, pesantren membekali santrinya berupa pengetahuan agama Islam yang cukup melalui kajian kitab kuning sebagai sumber pengetahuan agama. Di satu sisi, permohonan akan kehidupan dunia dan akhirat dengan kebaikan yang selalu menyelimuti seluruh aktifitas yang tentunya tidak lain adalah agar dapat menempatkan mereka di Surga.

Pendalaman agama yang diajarkan di pesantren cukup menempatkannya pada bentuk lembaga pendidikan Islam yang lebih membentuk afeksi santri agar terbentuk 
karakter manusia yang shalih. Pesantren memiliki ciri khas yang terbentuk secara tradisional yang mempunyai hubungan yang kuat di kalangan pesantren itu sendiri. Dalam penjelasan lain juga dijelaskan tentang ciri-ciri pesantren dan juga pendidikan yang ada didalamnya, maka ciri-cirinya adalah sebagai berikut ${ }^{6}$ :

a. Adanya hubungan akrab antar santri dengan kiainya Kondisi keakraban terlihat manakala kyai bersama para santrinya membangun pesantren. Pergaulan kyai dan santri begitu dekat jika dibandingkan dengan kepala sekolah terhadap murid-muridnya.

b. Adanya kepatuhan santri kepada kiai

Keterpengaruhan kyai bagi santrinya sangat tampak, terutama pada perintahperintah yang selalu dipenuhi oleh para santri. Mereka tidak pernah menolak perintahnya sang kyai, karena mereka mengharap barokah dengan mematuhinya, bahkan ludah pun menjadi idaman bagi para santri.

c. Hidup hemat dan sederhana benar-benar diwujudkan dalam lingkungan pesantren

Dalam lingkungan pesantren, terbiasa adanya kesamaan dalam perilaku dan tindakan karena ciri khasnya hidup sederhana tanpa ada yang boleh berlebihlebihan dalam gaya hidup. Dengan demikian para santri terbiasa menikmati kesederhanaan dan efisien dalam mengolah dan memanaj kehidupannya.

\footnotetext{
${ }^{6}$ Sulthon Masyhud dan Khusnurdilo, 2003, Manajemen Pondok Pesantren, Jakarta: DivaPustaka, Hlm. 93-94
} 


\section{Fauziah}

d. Kemandirian sangat terasa di pesantren

Kemandirian merupakan usaha menjalankan dan melakukan sendiri setiap perilakunya. Sementara di kalangan pesantren, para santri tidak di damping oleh keluarganya dan mereka tinggal di pondok untuk menuntut ilmu agama dan hidup mandiri bersama teman-teman santrinya.

e. Jiwa tolong-menolong dan suasana persaudaraan sangat mewarnai pergaulan di pesantren

Dikarenakan pola hidup sederhana dan kemandirian yang biasa dilakukan, maka muncullah jiwa tolong menolong dan suasana persaudaraan antar santri, yang mana mereka masing-masing juga mandiri tidak didampingi oleh keluarga, maka demikian juga tertanam semangat kekeluargaan yang kental.

f. Disiplin sangat dianjurkan

Sikap disiplin ditekankan dalam kehidupan di pesantren, karena upaya membentuk spiritual yang baik harus didampingi dengan kegiatan spiritual yang integratif. Kegiatan yang dilakukan di pesantren padat, dimana sejak bangun tidur, berangkat sekolah dan mengikuti pengajian yang padat menuntut mereka untuk selalu belajar disiplin dengan waktu istirahat tertentu.

g. Keprihatinan untuk mencapai tujuan mulia. Hal ini sebagai akibat kebiasaan puasa sunat, zikir, dan i'tikaf, shalat tahajud dan lain-lain Harapan didirikannya pesantren adalah semangat pengemblengan moral dan spiritual yang diisi dengan kegiatan ibadah yang memadai. Oleh karena itu, 
maka dengan kondisi di atas membentuk kebiasaan santri yang sering berpuasa, shalat malam serta rajin beri'tikaf di dalam masjid.

h. Pemberian ijazah, yaitu pencantuman nama dalam satu daftar rantai pengalihan pengetahuan yang diberikan kepada santri-santri yang berprestasi

Pendidikan Islam seharusnya memberikan arah bagaimana suatu lembaga dapat mengantarkan siswa-siswinya mampu berinteraksi dengan baik. Sebagaimana pandangan di atas, bahwa pendidikan pesantren telah mengajarkan bagaimana bersikap terhadap kyainya sebagai guru, keakraban yang mengabaikan pendidikan otoriter, serta hidup sederhana yang mengajak para santri sebagai pembelajar mampu bertahan dengan gaya dan model hidup yang tidak mudah silau dengan trend masyarakat, sehingga dengan demikian akan tercipta pertemanan yang dinamis dan tidak pilih kasih dalam pergaulan.

Kepatuhan santri kepada kyai menjadi titik sentral dalam setiap proses pembelajaran di pesantren. Disamping itu, kemandirian dan kedisiplinan memberikan ketahanan kepada santri untuk hidup sesuai dengan kebutuhan, ketepatan serta melakukan sendiri tanpa dibantu oleh orang tua dan sanak famili. Namun demikian suasana saling tolong menolong menjadi cermin budaya Islami yang tertanam juga dalam kehidupan di pesantren.

Kebiasaan positif yang harus ditanamkan pada pendidikan Islam yaitu lebih mengedepankan akhlak terutama pada gurunya. Dalam pada itu, kehidupan pesantren selalu mendorong santri untuk melakukan amaliyah spiritual dengan 


\section{Fauziah}

membiasakan beramal shalih, hal inilah yang ditunjukkan oleh pesantren dalam berperilaku yang baik.

Lembaga pendidikan Islam yang idealnya mencerminkan nuansa Islami seharusnya melaksanakan hal tersebut. Oleh karena itu, pesantren merupakan lembaga pendidikan Islam yang paling sesuai dalam melaksanakan secara utuh norma-norma Islami yang dengan demikian akan menjadikannya lembaga yang sanggup mempertahankan program keagamaan di zaman yang modern ini.

Perbedaan pemberian ijazah antara pesantren dengan lembaga pendidikan lainnya terletak pada lembaran yang kerap dipakai sebagai tanda kelulusan seorang siswa. Sementara itu, ijazah yang diberikan kepada lulusan pesantren yang lebih utama adalah transformasi keilmuan dan amaliyah yang disalurkan kepada santrinya. Disamping itu, pendidikan di madrasah harus diakhiri ketika sudah tamat dari jenjang tertentu, sementara pesantren tidak membatasi umur dan usia santri yang berkenan menimba ilmu di dalamnya walaupun harus "mondok" dengan keadaan sederhana dan dalam waktu lama tanpa tuntutan pendidikan tinggi.

\section{Pesantren sebagai Lembaga Pendidikan Islam yang Efektif}

Lembaga pendidikan yang efektif merupakan lembaga pendidikan yang mampu menghadirkan lulusannya yang sesuai dengan kebutuhan masyarakat. Kebutuhan tersebut dapat berupa ilmu pengetahuan yang dapat memberikan sumbangsih pemikiran dan tindakan yang dapat memecahkan persoalan sosial. 
Kontribusi nyata dapat dirasakan oleh masyarakat melalui mutu lulusan yang memadai serta dapat menjangkau wilayah-wilayah terkecil di dalamnya. Oleh karena itu, pengetahuan agama merupakan sebuah kebutuhan nyata yang tanpa disadari memberikan penyadaran kepada masyarakat akan pentingnya melakukan segala aktifitas spiritual dengan benar. Dalam hal ini, perlu dipertimbangkan program yang dapat mewadahi pengetahuan keagamaan yang kuat disamping pengetahuan umum yang harus juga dimiliki oleh lulusan lembaga pendidikan Islam.

Pesantren sebagai salah satu lembaga pendidikan Islam yang bergerak dalam membina spiritual santri tentunya telah menjalankan perannya sebagai agen pengetahuan agama. Dampak riil para lulusan begitu tampak nyata untuk memecahkan persoalan masyarakat Indonesia. Hal ini tampak sejak peristiwa kemerdekaan yang tidak lepas dari peran kyai dan santri yang membawa semangat Hubbul Wathan Min al-Iman (Cinta tanah air adalah sebagian dari iman). Oleh karena itu, pendidikan yang nyata dari interaksi pada ketawadhu'an orang yang beragama telah mengantarkan pada terlaksananya tujuan pendidikan Islam yang diidamidamkan.

Dibandingkan dengan lembaga pendidikan lainnya, sepertinya pesantren lebih konsisten dalam membangun semangat pendidikan Islam. Realitas ini sangat terasa hadirnya jika dilihat pada model lembaga pendidikan Islam yang lainnya yang lebih mengutamakan kognitif dalam pengetahuan umum, maka dalam beberapa hal agaknya pemikiran konseptual pengembangan pendidikan Islam dan beberapa 


\section{Fauziah}

kebijakan yang diambil kadang-kadang terkesan menggebu-gebu, idealis, atau bahkan kurang realistis. Sebagai para pelaksana di lapangan kadang-kadang mengalami beberapa hambatan dan kesulitan untuk merealisasikannya atau bahkan intensitas pelaksanaan dan efektifitasnya masih dipertanyakan. ${ }^{7}$

Untuk memperjelas orientasi dalam pengelolaan suatu lembaga pendidikan Islam ini, efektifitas, efisiensi, dan produktifitas menjadi prasyarat utama. Bagaimana mengelola lembaga pendidikan yang memiliki daya tarik dan mampu menjawab kebutuhan masyarakat. Pesantren sebagai lembaga pendidikan yang bercorak tradisional membawa kesan efektif dalam pendalaman agama, efisien dalam mengelola pembiayaan yang tidak membutuhkan banyak anggaran yang dapat menyedot dana dari wali santri dan masyarakat serta produktifitas dalam menghasilkan lulusan yang unggul dalam agama dan tidak menutup kemungkinan dalam beberapa pesantren yang menyelenggarakan keahlian tertentu yang dibekali untuk terjun di masyarakat.

Arus globalisasi mengharuskan terlibatnya sarana infomasi yang semakin canggih yang tidak bisa terbantahkan lagi terutama dalam menginformasikan keberadaan pesantren sekaligus ajang sosialisasi pada segenap masyarakat. Kondisi ini membawa komunitas pesantren ikut andil dalam perubahan yang signifikan dimana pengetahuan umum perlu mendapat porsi di dalam materi tambahan di pesantren.

\footnotetext{
${ }^{7}$ Muhaimin, 2002, Paradigma Pendidikan Islam: Upaya Mengefektifkan Pendidikan Agama Islam di Sekolah, Bandung : Remaja RosdaKarya
} 
Dengan adanya tranformasi, baik kultur, sistem dan nilai yang ada di pondok pesantren, maka kini pondok pesantren yang dikenal dengan salafiyah (kuno) kini telah berubah menjadi khalafiyah (modern). Transformasi tersebut sebagai jawaban atas kritik-kritik yang diberikan pada pesantren dalam arus transformasi ini, sehingga dalam sistem dan kultur pesantren terjadi perubahan yang drastis diantaranya 8 :

1. Perubahan sistem pengajaran dari perseorangan atau sorogan menjadi sistem klasikal yang kemudian kita kenal dengan istilah madrasah (sekolah).

2. Pemberian pengetahuan umum disamping masih mempertahankan pengetahuan agama dan bahasa arab.

3. Bertambahnya komponen pendidikan pondok pesantren, misalnya keterampilan sesuai dengan kemampuan dan kebutuhan masyarakat, kesenian yang Islami.

4. Lulusan pondok pesantren diberikan syahadah (ijazah) sebagai tanda tamat dari pesantren tersebut dan ada sebagian syahadah tertentu yang nilainya sama dengan ijazah negeri.

Perubahan sistem pembelajaran di pesantren terjadi karena dorongan arus globalisasi yang menjangkau kebertahanan gaya belajar santri. Keahlian tambahan yang mulai dirintis merupakan pemikiran baru yang terdorong dari keresahan masyarakat modern dimana muncul pertanyaan apakah putra-putrinya dapat bekerja setelah lulus dari pesantren. Oleh karena itulah, maka keterampilan

\footnotetext{
${ }^{8}$ Abdul Mujib, 2006, Ilmu Pendidikan Islam, Jakarta: Kencana Penada Media, Hlm. 235
} 


\section{Fauziah}

tambahan sedikit demi sedikit bermunculan untuk menjawab keresahan mereka. Disamping itu, sistem sorogan yang lebih dikenal secara privat kini berganti menjadi jama'i yang terdorong oleh banyaknya jumlah santri serta diperlukannya bentuk madrasah yang menjadi lembaga formal yang diberikan untuk membekali pengetahuan umumnya.

Dalam menyelenggarakan pendidikan pesantren, maka terdapat beberapa bentuk dan pola yang berbeda. Menurut Yacub ada beberapa pembagian tipologi pondok pesantren yaitu9:

1. Pesantren Salafi yaitu pesantren yang tetap mempertahankan pelajaran dengan kitab-kitab klasik dan tanpa diberikan pengetahuan umum. Model pengajarannya pun sebagaimana yang lazim diterapkan dalam pesantren salaf yaitu dengan metode sorogan dan weton.

2. Pesantren Khalafi yaitu pesantren yang menerapkan sistem pengajaran klasikal (madrasi) memberikan ilmu umum dan ilmu agama serta juga memberikan pendidikan keterampilan.

3. Pesantren Kilat yaitu pesantren yang berbentuk semacam training dalam waktu relatif singkat dan biasa dilaksanakan pada waktu libur sekolah. Pesantren ini menitikberatkan pada keterampilan ibadah dan kepemimpinan. Sedangkan santri terdiri dari siswa sekolah yang dipandang perlu mengikuti kegiatan keagamaan di pesantren kilat.

${ }^{9}$ Khosin, 2006, Tipologi Pondok Pesantren, Jakarta: diva Pustaka, Hlm. 101 
4. Pesantren terintegrasi yaitu pesantren yang lebih menekankan pada pendidikan vocasional atau kejuruan sebagaimana balai latihan kerja di Departemen Tenaga Kerja dengan program yang terintegrasi. Sedangkan santri mayoritas berasal dari kalangan anak putus sekolah atau para pencari kerja.

Keempat tipologi pesantren sebagaimana dikemukakan oleh Yacub, pada zaman ini masih ada di wilayah Indonesia. Pada pesantren Salafi dapat ditemukan di pesantren yang masih menjada sistem kuno yang tidak memberikan ruang sama sekali dalam pengetahuan umum sehingga materi dan sistemnya cenderung stabil. Sementara itu, terdapat pesantren Khalafi yang mempertemukan antara pengetahuan agama melalui pengajian di pesantren serta pengetahuan umum melalui pengajaran di madrasah. Model ini pada zaman sekarang relatif lebih banyak ditemukan karena dianggap dapat memenuhi kebutuhan masyarakat dalam masa depan putranya. Pesantren kilat sering ditemui pada saat bulan Ramadhan yang dikaji berkaitan dengan ibadah puasa dan lainnya. Sedangkan pesantren terintegrasi juga mengalami perkembangan dengan menawarkan beberapa keterampilan seperti kursus menjahit, berkebun, teknik dan keahlian lainnya.

Pesantren yang mempertahankan kemurnian identitas asli sebagai tempat mendalami ilmu-ilmu agama (tafaqquh fi ad-din) bagi para santrinya. Semua materi yang diajarkan di pesantren ini sepenuhnya bersifat keagamaan yang bersumber dari kitab-kitab berbahasa arab (kitab kuning) yang ditulis oleh para ulama' abad pertengahan. Pesantren model ini masih banyak kita jumpai hingga sekarang seperti 


\section{Fauziah}

pesantren Lirboyo di Kediri Jawa Timur beberapa pesantren di daerah Sarang Kabupaten Rembang Jawa tengah dan lain-lain ${ }^{10}$.

Karakteristik pesantren salaf tetap akan mempertahankan model pengajian dan tak akan lekang oleh waktu, hal ini disebabkan pesan yang dititipkan oleh pendiri yang harus terus dijaga sekaligus menjadi khas bagi pesantren tersebut. Di beberapa pesantren ada yang telah mengembangkan sistem pendidikannya dengan mendirikan madrasah bahkan perguruan tinggi untuk mewadahi keahlian lulusan yang siap pakai dalam segala bidang.

Namun persoalan yang kerap menghantui segenap santri yang mengenyam pendidikan agama di pesantren yakni bahwa pesantren yang memasukkan materimateri umum dalam pengajaran namun dengan kurikulum yang disusun sendiri menurut kebutuhan dan tak mengikuti kurikulum yang ditetapkan pemerintah secara nasional sehingga ijazah yang dikeluarkan tak mendapatkan pengakuan dari pemerintah sebagai ijazah formal11. Oleh karena itulah, maka pada zaman kini muncul keresahan bagi lulusan dalam rangka mempersiapkan masa depannya tidak hanya pengetahuan agama namun juga umum yang dapat diakui khalayak ramai.

Pesantren yang menyelenggarakan pendidikan umum di dalam baik berbentuk madrasah (sekolah umum berciri khas Islam di dalam naungan Kemenag) maupun sekolah (sekolah umum di bawah Kemendikbud) dalam berbagai jenjang bahkan ada yang sampai Perguruan Tinggi yang tak hanya meliputi fakultas-fakultas keagamaan

\footnotetext{
${ }^{10}$ Mas'ud, dkk, 2002, Tipologi Pondok Pesantren , Jakarta: Putra Kencana, Hlm. 149-150.

${ }^{11} \mathrm{Ibid}$, Hlm. 149-150.
} 
meliankan juga fakultas-fakultas umum, contohnya adalah Pesantren Tebu Ireng di Jombang Jawa Timur ${ }^{12}$.

Penyelenggaraan pendidikan formal dalam pesantren kini sudah menjadi trend di masyarakat sekaligus dianggap mampu menutupi keresahan tentang masa depan putranya. Namun bagi pesantren yang masih mempertahankan sistem salafnya namun memberi kelonggaran untuk menempuh pendidikan formal di luar juga banyak ditemukan, seperti halnya di Kecamatan Singosari Kabupaten Malang dimana berdiri beberapa pesantren besar yang tidak menyelenggarakan pendidikan formal tetapi santri di berbagai pesantren tersebut belajar di satu lembaga formal Madrasah di Yayasan al-Ma'arif Singosari, sementara itu siswa datang dari santri Pesantren Ilmu al-Qur'an (PIQ), Pesantren Nurul Huda, Pesantren al-Islahiyah, dan pesantren lainnya yang berkumpul di madrasah tersebut.

Pesantren yang merupakan asrama pelajar Islam dimana para santri belajar di sekolah-sekolah atau perguruan-perguruan tinggi di luarnya. Pendidikan agama di pesantren model ini diberikan di luar jam-jam sekolah sehingga bisa diikuti oleh semua santrinya, diperkirakan pesantren model inilah yang terbanyak jumlahnya ${ }^{13}$.

Dalam melaksanakan pendidikan agama Islam di pesantren model ini, santri memiliki keleluasaan untuk tetap mendalami agama di pesantren juga bisa mendapatkan ijazah yang akan diakui oleh pemerintah melalui pendidikan formal. Secara garis besar, sebenarnya pesantren memiliki andil untuk menjaga dan

\footnotetext{
${ }^{12}$ Ibid, Hlm. 149-150.

${ }^{13} \mathrm{Ibid}, \mathrm{Hlm} .149-150$.
} 


\section{Fauziah}

mendidik santrinya tanpa pengaruh dari luar sehingga pendampingan dan penanaman kegiatan spiritual secara mandiri dapat dilakukan pemantauan dengan ketat.

Pendalaman spiritual yang digaungkan kalangan pesantren memiliki karakteristik yang berbeda antara satu dengan lainnya. Hal ini tidak lepas dari peran kyai dan pendiri yang berusaha sekuat tenaga mengemban tugas penggemblengan mental spiritual yang berakibat sistem pendidikan yang diselenggarakan berbeda.

Sistem yang ditampilkan dalam pondok pesantren mempunyai keunikan dibandingkan dengan sistem yang diterapkan dalam lembaga pendidikan pada umumnya, yaitu ${ }^{14}$ :

1. Memakai sistem tradisional, yang memiliki kebebasan penuh dibandingkan dengan sekolah modern, sehingga terjadi hubungan 2 arah antara kiai dan santri.

2. Kehidupan di pesantren menampakkan semangat demokrasi, karena mereka praktis bekerjasama mengatasi problem non kurikuler mereka sendiri.

3. Para santri tidak mengidap penyakit simbolis, yaitu perolehan gelar dan ijazah, karena sebagian besar pesantren tidak mengeluarkan ijazah, sedangkan santri dengan ketulusan hatinya masuk pesantren tanpa adanya ijazah tersebut. Hal itu karena tujuan utama mereka hanya ingin mencari keridhoan Allah SWT semata.

4. Sistem pondok pesantren mengutamakan kesederhanaan, idealisme, persaudaraan, persamaan, rasa percaya diri, dan keberanian hidup.

\footnotetext{
${ }^{14}$ Amien Rais, 1989, Cakrawala Islam: Antara Cita dan Fakta, Bandung: Mizan, Hlm 162. 
5. Alumni pondok pesantren tak ingin menduduki jabatan pemerintahan, sehingga mereka hampir tidak dapat dikuasai oleh pemerintah.

Metode pendidikan pesantren yang kerap muncul adalah dengan sistem wetonan dan sorogan. Adapun wetonan merupakan sistem pengajian yang banyak ditemukan di pembelajaran kitab saat ini yaitu kyai menyampaikan dan menjelaskan isi kitab yang didengarkan oleh santri dengan menyimak dan mencatat makna dari kitab yang dibawa oleh santri. Sementara itu metode sorogan merupakan sistem pengajian yang sudah mulai ditinggalkan mengingat jumlah santri bertambah banyak dimana sistem ini mengajak santri untuk belajar sendiri tentang suatu kitab untuk kemudian dibacakan di hadapan kyai dengan menterjemahkan dan memaknai satu persatu. Namun sistem ini juga masih ditemukan secara personal dimana santri datang ke rumah kyai untuk mentashih kebenaran bacaan dan pemahaman santri.

Disamping itu terdapat metode hafalan yang berlangsung dimana santri menghafal teks atau kalimat tertentu dari kitab yang dipelajarinya. Materi hafalan biasanya dalam bentuk syi'ir atau nadzam. Sebagai pelengkap metode hafalan sangat efektif untuk memelihara daya ingat (memorizing) santri terhadap materi yang dipelajarinya, karena dapat dilakukan baik di dalam maupun di luar kelas. ${ }^{15}$

Sedangkan jenjang pendidikan dalam pesantren tidak dibatasi seperti dalam lembaga-lembaga pendidikan yang memakai sistem klasikal. Umumnya, kenaikan tingkat seorang santri didasarkan isi mata pelajaran tertentu yang ditandai dengan

\footnotetext{
${ }^{15}$ Sulthon Masyhud dan Khusnurdilo, Op.Cit, Hlm. 89
} 


\section{Fauziah}

tamat dan bergantinya kitab yang dipelajarinya. Apabila seorang santri telah menguasai satu kitab atau beberapa kitab dan telah lulus ujian (imtihan) yang diuji oleh kiainya, maka ia berpindah ke kitab lain yang lebih tinggi tingkatannya. Jelasnya, penjenjangan pendidikan pesantren tidak berdasarkan usia, tetapi berdasarkan penguasaan kitab-kitab yang telah ditetapkan dari paling rendah sampai paling tinggi.

Sebagaimana ditemukan di beberapa pesantren bahwa pembelajaran kitab kuning dimaknai sebagai materi yang mengandung unsur barakah melalui penyampaian kyai yang telah mempelajari ilmu agama dari guru-gurunya. Oleh karena itu, diharapkan dari pengajian tersebut akan memberikan ruang barakah bagi santri yang ikhlas dan bersungguh-sungguh dalam mengabdikan diri di pesantren. Dengan demikian maka pendidikan pesantren lebih efektif untuk pendidikan agama yang secara langsung diterapkan dalam kehidupan sehari-hari.

Pesantren sebagai agen pendidikan agama Islam menyelenggarakan pendidikan agama yang efektif. Hal ini jelas diterangkan bahwa penyelenggaraan pendidikan harus memperhatikan efektifitas yang memadai agar dapat dirasakan oleh masyarakat. Sebagaimana dijelaskan bahwa efektifitas pendidikan dalam setiap tahapannya berproses pada dos sollen dan dossein dengan indikator-indikator sebagai berikut ${ }^{16}$ :

${ }^{16}$ Ibid 
1. Indikator input; meliputi karakteristik guru, fasilitas, perlengkapan dan materi pendidikan serta kapasitas manajemen.

2. Indikator proses; meliputi prilaku administratif, alokasi waktu guru, dan alokasi waktu peserta didik.

3. Indikator out put; berupa hasil-hasil dalam bentuk perolehan peserta didik meliputi hasil prestasi belajar, sikap, keadilan dan persamaan.

4. Indikator out come; meliputi jumlah lulusan ke tingkat pendidikan berikutnya, prestasi belajar di sekolah yang lebih tinggi dan pekerjaan serta pendapatan.

Keefektifitasan pendidikan di pesantren tidak lepas dari adanya profesionalisme seorang kyai yang dengan kematangan pengetahuan agamanya serta kecakapannya dalam menguasai kitab kuning, maka membawa pendidikan efektif dalam menghasilkan output yang baik. Proses pendidikan yang diterapkan di pesantren begitu padat untuk pengajian kitab kuning sehingga secara waktu tidak dapat diukur batasan jam pertemuannya. Namun demikian biasanya pengajian dilaksanakan $b a^{\prime} d a$ shubuh secara rutin, $b a^{\prime} d a$ ashar, $b a^{\prime} d a$ maghrib ataupun $b a^{\prime} d a$ isya. Hal ini menandakan konsistensi dan istiqomah dilakukan dengan baik tanpa mengenal hari libur nasional dibandingkan dengan madrasah yang hadir meliburkan secara mendadak jika ada aturan dari instansinya yang tentunya akan merubah perencanaan yang telah dibuat oleh guru. 


\section{Fauziah}

\section{D.Penutup}

Pesantren merupakan sistem pendidikan yang berorientasi pada pendidikan akhlak melalui pendalaman agama yang dicirikan pada adanya kyai, santri, masjid, pondok serta kajian kitab-kitab klasik yang dapat dijadikan pegangan oleh kalangan pesantren. Pokok pendidikan pesantren adalah bagaimana aspek spiritual dapat dijalankan dengan baik melalui pengajian tanpa memandang perbedaan dengan lembaga lain.

Konsep lembaga pendidikan yang efektif secara umum dapat dilihat dari adanya output yang sesuai dengan tujuan dan perencanaan yang telah dibuat. Dalam hal ini pesantren telah menjalankan tugasnya mengantarkan lulusannya mampu menguasai agama dengan sangat baik bahkan melebihi dari kemampuan agama yang diselenggarakan di madrasah.

Prinsip yang dipegang dalam pendidikan pesantren adalah bagaimana manusia dapat menjaga dirinya dan keluarganya serta masyarakat sekitar terbebas dari siksa api neraka di akhirat kelak sehingga di dalamnya diajarkan akidah yang benar, akhlak sebagai interaksi amal shalih serta fiqh yang menjadi acuan dalam melaksanakan ibadah yang benar sesuai tuntunan Syari'at. 


\section{Daftar Pustaka}

Azra, Azyumardi. dalam pengantar Abudin Nata (editor). 2001. Sejarah Pertumbuhan dan Perkembangan Lembaga-Lembaga Pendidikan Islam Di Indonesia. Jakarta: Grasindo

Khosin. 2006. Tipologi Pondok Pesantren. Jakarta: Diva Pustaka

Mas'ud, dkk. 2002. Tipologi Pondok Pesantren. Jakarta: Putra Kencana

Masyhud, Sulthon dan Khusnurdilo. 2003. Manajemen Pondok Pesantren. Jakarta: Diva Pustaka

Muhaimin. 2002. Paradigma Pendidikan Islam: Upaya Mengefektifkan Pendidikan Agama Islam di Sekolah. Bandung : Remaja Rosdakarya

Mujib, Abdul. 2006. Ilmu Pendidikan Islam. Jakarta: Kencana Penada Media

Nizar, Samsul. 2001. Lembaga Pendidikan Islam di Nusantara. Jakarta: Grasindo

Rais, Amien. 1989. Cakrawala Islam: Antara Cita dan Fakta. Bandung: Mizan

Sagala, Syaiful. 2006. Konsep dan Makna Pembelajaran. Bandung : alfabeta . cet.4

Tafsir, Ahmad. 2006. Filsafat Pendidikan Islami: Integrasi Jasmani, Rohani dan Kalbu Memanusiakan Manusia. Bandung: Remaja Rosdakarya

Uluum, Manba'ul. 2012. Filsafat Pendidikan Islam; Lembaga Pendidikan Islam dan Tantangan Modernisasi. Diakses tanggal 3 Maret 2013 pada, http://manbaululuumgs, blogspot.com 


\section{Fauziah}

